\title{
Lapisan Pemahaman Mahasiswa Calon Guru Matematika Dengan Tipe Middle Ability Dalam Menyelesaikan Soal Pembuktian Grup Berdasarkan Teori Pirie-Kieren
}

\author{
Novita Eka Muliawati
}

(C) 2020 JEMS (Jurnal Edukasi Matematika dan Sains)

This is an open access article under the CC-BY-SA license (https://creativecommons.org/licenses/bysa/4.0/) ISSN 2337-9049 (print), ISSN 2502-4671 (online)

\begin{abstract}
Abstrak:
Penelitian ini bertujuan untuk mendeskripsikan lapisan pemahaman mahasiswa calon guru matematika dengan tipe middle ability dalam menyelesaikan soal pembuktian grup berdasarkan teori Pirie Kieren. Jenis penelitian ini merupakan penelitian kualitatif, dengan subjek penelitian yaitu mahasiswa program studi pendidikan matematika STKIP PGRI Tulungagung Semester VI Tahun akademik 2019/2020 yang baru saja mengampu mata kuliah struktur aljabar 1 yang mengkaji tentang grup. Instrumen penelitian ini berupa tes lapisan pemahaman pembuktian grup (TLP2G) dan pedoman wawancara. Data penelitian yang dikumpulkan berupa hasil TLP2G dan hasil wawancara. Analisis data dalam penelitian ini terdiri dari tiga tahapan yaitu reduksi data, penyajian data, dan penarikan kesimpulan. Hasil penelitian menunjukkan bahwa mahasiswa calon guru matematika dengan tipe middle ability memiliki lapisan pemahaman sampai pada lapisan ke-7 yaitu primitive knowing, image making, image having, property noticing, formalizing, observing, structuring. Pada lapisan ke-8 yaitu inventising, subjek penelitian belum mencapai lapisan tersebut, karena masih belum mampu mengungkapkan pertanyaanpertanyaan baru di luar TLP2G yang dapat membentuk konsep baru.
\end{abstract}

Kata Kunci : grup; lapisan pemahaman; middle ability, piriekieren

\section{Pendahuluan}

Salah satu mata kuliah yang menjadi momok bagi mahasiswa program studi pendidikan matematika di STKIP PGRI Tulungagung yaitu mata kuliah struktur aljabar. Hal ini, dapat dilihat dari data hasil nilai UAS pada mata kuliah tersebut. Hasil UAS menunjukkan $80 \%$ maha-

\begin{abstract}
:
This research aimed to describes the level of understanding of student mathematics teacher candidates with the middle ability type in solving of proving group problems based on Pirie Kieren's theory. This type of research is qualitative research, with the research subject, namely students of the Mathematics Education Study Program STKIP PGRI Tulungagung Semester VI of the 2019/2020 academic year who have just taught algebra structure 1 which studies about groups. The research instrument was a the level understanding proving group test (TLP2G) and interview guidelines. The research data collected is in the form of TLP2G results and interview results. Data analysis in this study consisted of three stages, namely data reduction, data presentation, and drawing conclusions. The results showed that the middle ability type of mathematics teacher students had a level of understanding up to the 7th level, namely primitive knowing, image making, image having, property noticing, formalizing, observing, structuring. At the 8th level, namely inventory, research subjects have not reached that levelr, because they are still unable to reveal new questions outside of TLP2G that can form new concepts.
\end{abstract}

Keywords : grup; level of understanding; middle ability, piriekieren 
siswa kurang tepat dalam menyelesaikan soal uas struktur aljabar, khususnya pada materi pembuktian grup. Ketidaktepatan dalam menyelesaikan soal pembuktian grup disebabkan karena kurang kuatnya pemahaman mahasiswa terkait konsep pembuktian grup. Selain pemahaman yang kurang, koherensi antar materi yang telah dipelajari belum menyatu pada struktur kognitif mahasiswa. Pemahaman dalam pembelajaran matematika memegang peranan penting dalam tercapainya tujuan pembelajaran matematika yang telah ditentukan.

Lebih lanjut, Hiebert dan Carpenter dalam (Jung, 2002) menyatakan "One of the most widely accepted ideas within the mathematics education community is the idea that student should understand mathematics". Pernyataan Hiebert dan Carpenter dapat diartikan bahwa yang paling penting dalam pembelajaran matematika adalah ide yang seharusnya dipahami siswa. Sependapat dengan Hiebert dan Carpenter, The National Council of Teachers of Mathematics menyatakan bahwa pemahaman matematis merupakan aspek yang penting dalam pembelajaran matematika (Utami, 2016) Sehingga, dapat disimpulkan bahwa dalam pembelajaran matematika, salah satu aspek yang perlu ditekankan adalah pemahaman matematis yang dimiliki siswa.

Pemahaman merupakan topik yang menarik. Berbagai teori telah muncul untuk menjelaskan pertumbuhan pemahaman matematis. Beberapa teori tersebut antara lain Teori Skemp pada tahun 1987, Teori Hiebert dan Carpenter tahun 1992, Teori Pirie dan Kieren tahun 1994 serta Teori Sierpinska pada tahun 1994 dan masih banyak lagi. Teori-teori tersebut memiliki pendapat yang sama yaitu pemahaman seseorang berada pada pikirannya sendiri. Pemahaman seseorang dapat berubah setiap waktu. Seseorang dapat dikatakan paham diketahui dari hasil analisis fakta yang ada. Sehingga, pada penelitian ini diasumsikan pemahaman mahasiswa dapat diketahui melalui penjelasan mahasiswa dalam mengerjakan soal dan interaksi yang terjadi antara subjek dan peneliti.

Pirie dan Kieren telah memberikan kerangka teoritis tentang delapan level (lapisan) pemahaman. Bruner dan Piaget dalam sebagian besar karyanya sendiri berkonsentrasi pada pengembangan pengetahuan matematika di usia dini, jarang melampaui masa remaja, namun Dubinsky tertarik melakukan penelitian dengan pendekatan yang sama dan diperluas untuk topik yang lebih tinggi hingga materi pelajaran matematika bagi sekolah menengah atas bahkan perguruan tinggi. Ketika itu Dubinsky melihat kemungkinan, tidak hanya untuk membahas dan menduga, tetapi untuk memberikan bukti yang menunjukkan bahwa konsep-konsep seperti induksi matematika, proposisi dan kalkulus predikat, fungsi sebagai proses dan objek, kebebasan linear, dan seterusnya, dapat dianalisis dalam hal perpanjangan/perluasan dari gagasan yang sama seperti yang dilakukan Piaget (Viktor, 2016).

Hampir semua teori pemahaman di atas kecuali Teori Pirie - Kieren menganggap bahwa pemahaman merupakan proses yang linear. Pirie - Kieren menganggap pemahaman merupakan proses pertumbuhan yang utuh, dinamis, berlapis tetapi tidak linear dan tidak pernah berakhir. Proses pemahaman ini digambarkan seperti bawang yang memiliki lapisan-lapisan. Lapisanlapisan tersebut antara lain Primitive knowing, Image having, Image making, Property noticing, Formalising, Observing, Structuring, dan Inventising (Pirie-Kieren, 1994). Sesuai dengan anggapan pemahaman merupakan proses yang tidak pernah berakhir, sehingga pemahaman pada inventising sering menjadi primitive knowing materi baru. Lapisan-lapisan pemahaman merupakan salah satu keistimewaan dari teori ini. Keistimewaan lain dari teori ini adalah adanya komponen-komponen penyusun tiap lapisan dan adanya folding back yang merupakan kegiatan kembali ke lapisan terdalam apabila mengalami suatu kendala dalam menyelesaikan soal atau 
permasalahan pada lapisan yang lebih luar. Adapun 8 lapisan pemahaman tersebut dapat ditunjukkan pada gambar berikut ini:

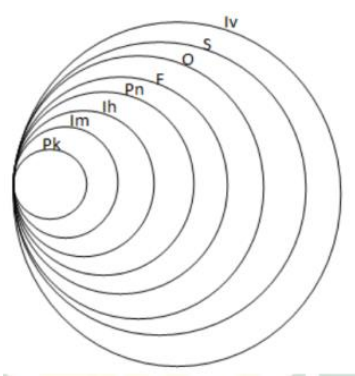

\section{Gambar 1. Level Pertumbuhan Pemahaman Matematis Model Pirie-Kieren}

Gambar dari lapisan pemahaman tersebut seperti lapisan pada kulit bawang. Lapisan terdalam sampai terluar menunjukkan tingkatan atau level pemahaman yang dicapai oleh seseseorang.

Pirie-Kieren membagi lapisan pemahaman menjadi delapan level pemahaman dimana semakin menuju ke lapisan terluar maka tingkat pemahaman siswa akan suatu hal tersebut semakin tinggi. Ngalim Purwanto mengungkapkan tingkat keberhasilan siswa dalam mempelajari matematika dipengaruhi oleh faktor internal dan eksternal (Ngalim, 2007) Salah satu faktor internal yang mempengaruhi tingkat pemahaman mahasiswa adalah kemampuan matematika mahasiswa itu sendiri. Kemampuan matematika mahasiswa dapat menentukan tingkat pemahaman mahasiswa terhadap makna dan konsep dari soal atau permasalahan yang dihadapinya. Kemampuan matematika mahasiswa berbeda-beda, ada yang memiliki kemampuan tinggi, sedang, dan rendah. Blinder menyatakan bahwa mahasiswa yang memiliki kemampuan matematika tinggi akan memberikan pemikiran kreatif dalam tugas matematika baru dan menyediakan solusi bermakna dan asli. Mahasiswa yang mempunyai kemampuan matematika tinggi akan lebih mudah mengkonstruksi pengetahuannya dibanding mahasiswa yang mempunyai kemampuan matematika sedang dan rendah (Khoirun, 2014).

Viktor Sagala juga melakukan penelitian terkait lapisan pemahaman dan folding back pada konsep turunan fungsi. Penelitian tersebut dilakukan pada mahasiswa calon guru yang berkemampuan matematika tinggi saja. Dalam penelitiannya, Viktor Sagala mendapatkan hasil bahwa mahasiswa calon guru yang berkemampuan matematika tinggi dapat mencapai hingga lapisan terluar menurut teori lapisan pemahaman Pirie-Kieren (viktor, 2016). Hal tersebut menunjukkan bahwa mahasiswa yang berkemampuan matematika tinggi memiliki tingkat pemahaman yang baik pada konsep turunan fungsi. Penelitian tersebut hanya meneliti mahasiswa berkemampuan matematika tinggi saja, sehingga kita belum mengetahui sejauh mana tingkat pemahaman matematis siswa dengan kemampuan matematika yang berbeda menurut teori Pirie-kieren.

Berdasarkan uraian di atas, penelitian ini mengkaji tentang lapisan pemahaman mahasiswa calon guru matematika dengan tipe middle ability dalam menyelesaikan soal pembuktian grup berdasarkan teori pirie-kieren. Tujuan dari penelitian ini yaitu mendeskripsikan lapisan pemahaman mahasiswa calon guru matematika dengan tipe middle ability dalam menyelesaikan soal pembuktian grup berdasarkan teori pirie-kieren. Hal ini penting untuk dikaji, karena sebagai 
calon guru, harus bisa beradaptasi dengan cepat terhadap perkembangan dunia pendidikan termasuk harus selalu uptodate terkait teori-teori dalma pembelajaran matematika sehingga para calon guru mampu mengaktualisasi diri dengan baik dan professional. Seperti halnya mengaktualisasi diri dalam hal pemahaman terhadap segala macam bentuk konsep dalam matematika, sehingga mampu mencapai level pemahaman yang baik seperti level ke-8 pada teori pirie-kieren yaitu mencapai level inventising.

\section{Metode}

Penelitian ini merupakan penelitian deskriptif eksploratif yang mendeskripsikan secara rinci dan apa adanya mengenai lapisan pemahaman mahasiswa calon guru matematika dengan tipe middle ability dalam menyelesaikan soal pembuktian grup. Materi yang digunakan adalah materi yang sudah dipelajari yaitu pembuktian grup, yang baru saja di ampu oleh mahasiswa semester VI program studi pendidikan matematika STKIP PGRI Tulungagung. Subjek pada penelitian ini adalah mahasiswa semester VI program studi pendidikan matematika STKIP PGRI Tulungagung pada tahun akademik 2019/2020 yang sudah mengampu mata kuliah struktur aljabar 1, yang focus mengkaji tentang grup.

Penentuan subjek dalam penelitian ini dilakukan dengan mengkaji dan mengevaluasi hasil ujian tengah semester (UTS) mahasiswa. Hasil evaluasi UTS ini di jadikan acuan untuk menentukan level kemampuan mahasiswa masuk pada kategori 3 kategori yaitu: high ability, middle ability, dan low ability. Pada penelitian ini fokus subjeknya pada mahasiswa yang memiliki middle ability. Berdasarkan hasil UAS maka diperoleh data sebagai berikut:

Tabel 1. Hasil Evaluasi Tengah Semester Mata Kuliah Struktur Aljabar 1

\begin{tabular}{ccccc}
\hline \multirow{2}{*}{ Kelas } & Jumlah & \multicolumn{4}{c}{ Persentase Hasil Berdasarkan Nilai } \\
& Mahasiswa & $0 \leq$ Nilai $<40$ & $40 \leq$ Nilai $<70$ & $70 \leq$ Nilai $<100$ \\
\hline \multirow{2}{*}{ A } & 18 & $16,6 \%$ & $55,6 \%$ & $27,8 \%$ \\
\hline
\end{tabular}

Hasil evaluasi nilai UTS menunjukkan 5 mahasiswa masuk pada kategori high ability, 10 mahasiswa masuk kategori middle ability, dan 3 mahasiswa masuk kategori low ability. Berdasarkan hasil evaluasi hasil nilai UTS tersebut, 10 mahasiswa yang masuk kategori lower middle di ambil menjadi subjek penelitian. Subjek penelitian yang sudah terpilih, kemudian diberikan tes yaitu tes lapisan pemahaman pembuktian grup (TLP2G). TLPG terdiri dari satu soal tentang pembuktian grup, yaitu pembuktian $G=\left(Z_{6},+\right)$, dimana $Z_{6}$ adalah himpunan modulo 6. Selain TLP2G, instrumen selanjutnya yaitu pedoman wawancara, yang isinya menyesuaikan dengan indikator lapisan pemahaman berdasarkan teori pirie-kieren.

Teknik analisis data yang digunakan pada penelitian ini yaitu: 1) mereduksi data yang merupakan kegiatan menyeleksi, memfokuskan dan menyederhanakan semua data yang diperoleh mulai dari awal pengumpulan data sampai penyusunan laporan penelitian, 2) penyajian data, yang merupakan kegiatan menyiapkan hasil reduksi data secara naratif kemudian penarikan kesimpulan, 3) penarikan kesimpulan dilakukan berdasarkan data yang telah disajikan dan merupakan kegiatan pengungkapan akhir dari hasil penelitian. Pada tahap ini, semua data yang diperoleh dari awal sampai data yang akhir di analisis secara mendalam, sehingga menghasilkan data yang akurat dan valid. Tahapan selanjutnya yaitu mengecek 
keabsahan data yang meliputi: 1) ketekunan pengamat, ketekunan pengamat berarti peneliti mengadakan pengamatan dengan teliti, rinci, dan terus menerus selama proses penelitian, 2) triangulasi, triangulasi merupakan teknik penarikan keabsahan data yang memanfaatkan sumber data yang berbeda dari data yang dikumpulkan untuk keperluan pengecekan atau sebagai pembanding terhadap data itu. Triangulasi pada penelitian ini menggunakan triangulasi metode yaitu mengecek data hasil TLP2G dengan data hasil wawancara, 3) pemeriksaan teman sejawat, pemeriksaan teman sejawat melalui diskusi, mendiskusikan proses dan hasil penelitian dengan teman yang sedang mengadakan penelitian kualitatif. Peneliti melakukan diskusi dengan sesama peneliti yang melakukan penelitian yang sejeni

\section{Hasil dan Pembahasan}

Setelah subjek penelitian yang bertipe middle ability menyelesaikan soal terkait pembuktian grup, maka dilakukan wawancara kepada subjek penelitian, untuk menggali dan mengeksplorasi data yang telah didapat melalui TLP2G dengan data hasil wawancara. Berdasarkan hasil analisis data maka diperoleh data bahwa subjek penelitian dengan middle ability mencapai lapisan pemahaman pada level ke-7 yaitu structuring. Pada setiap tahapan lapisan pemahaman, data yang diperoleh mengacu pada iondikator lapisan pemahaman menurut teori pirie-kieren.

Pada tahap awal yaitu lapisan ke-1/primitive knowing, data yang diperoleh menunjukkan subjek penelitian sudah mampu menuliskan informasi-informasi yang ada pada soal dengan benar seperti menuliskan yang diketahui, yang di tanyakan, dan mampu menjelaskan secara singkat definisi dari grup. Subjek mampu menuliskan dan menjelaskan definisi grup dengan tepat. Untuk informasi pada soal, subjek penelitian menuliskan yang diketahui dengan menuliskan kembali informasi pada soal yaitu menuliskan: $Z_{6}=\{0,1,2,3,4,5\}$ dan menuliskan kembali yang ditanyakan dengan: buktikan bahwa $\left(Z_{6},+\right)$ adalah suatu grup. Selain dari hasil pekerjaan subjek penelitian, hasil wawancara juga menunjukkan, subjek penelitian lancer dalam menjelaskan definisi grup dan juga menyebutkan yang diketahui dan yang ditanyakan. Pada tahap ke-1 yaitu level primitive knowing, subjek penelitian sudah memenuhi indikator lapisan pemahaman berdasarkan teori pirie-kieren. Hal ini sesuai dengan pendapat Safitri, Mulyani, \& Ratu (2018) bahwa siswa sudah mempunyai pemahaman awal yang berkaitan dengan topik dan mampu menjelaskan pengetahuan sederhana yang dimiliki

Pada tahap kedua yaitu lapisan ke-2/image making, data yang diperoleh menunjukkan subjek penelitian sudah mendapatkan gambaran atau ide yang akan dilakukan untuk membuktikan grup (TLP2G). Subjek juga mampu menjelaskan secara lengkap gambaran penyelesaian TLP2G dengan menuiskan seluruh anggota dari bilangan modulo 6 dari $Z_{6}$ definisi grup dengan tepat. Subjek penelitian mampu menjelaskan gambaran secara rinci terkait ideidenya yang terkait dengan penyelesaian pembuktian grup. Pada tahap ini, subjek penelitian masih sebatas menyampaikan ide-idenya terkait pembuktian grup pada TLP2G. Pada tahap ke2 yaitu level image making, subjek penelitian sudah memenuhi indikator lapisan pemahaman berdasarkan teori pirie-kieren.

Pada tahap ketiga yaitu lapisan ke-3/image having, data yang diperoleh menunjukkan subjek penelitian sudah menggunakan gambaran atau ide yang akan dilakukan untuk membuktikan grup (TLP2G). Subjek juga mampu menjelaskan secara lengkap cara yang digunakan untuk penyelesaian TLP2G dengan mengingat kembali konsep dari grup. Mulai dari 
menjelaskan tentang operasi biner yang bersifat tertutup, kemudian bersifat assosiatif, memiliki unsur identitas, dan memiliki invers. Subjek penelitian mampu menjelaskan konsep dari grup tersebut dengan baik, dan sangat memahami setiap itemnya. Pada tahap ini, subjek penelitian sudah siap menggunakan ide-idenya untuk menyelesaikan soal pada TLP2G. Pada tahap ke-3 yaitu level image having, subjek penelitian sudah memenuhi indikator lapisan pemahaman berdasarkan teori pirie-kieren.

Pada tahap keempat yaitu lapisan ke-4/property noticing, subjek penelitian sudah mampu menarik hubungan-hubungan antar informasi yang ada pada TLP2G sehingga dapat menemukan konsep baru untuk membuktikan grup (TLP2G) dimana informasi-informasi tersebut sudah didapatkan saat primitive knowing. Subjek juga mampu menjelaskan secara lengkap cara yang digunakan untuk penyelesaian TLP2G dengan mengingat kembali konsep dari bilangan modulo. Mulai dari menjelaskan bagaimana konsep bilangan modulo, bagaimana konsep dari himpunan yang ada pada bilangan modulo, bagaiman operasi penjumlahan pada bilangan modulo, sampai implementasi konsep grup pada penyelesaian soal yang terkait pembuktian grup dengan fokus pada bilangan modulo. Subjek penelitian mampu menjelaskan konsep dari bilangan modulo tersebut dengan baik, dan sangat memahami setiap itemnya. Pada tahap ini, subjek penelitian masih sangat baik mengungkapkan ide-idenya dan mengkombinasikan pengetahuan sebelumnya terkait konsep bilangan modulo. Hal ini menunjukkan bahwa subjek penelitian juga mampu me-recall kembali pengetahuannya yang tersimpan pada long term memory maupun short term memory. Pada tahap ke-4 yaitu level property noticing, subjek penelitian sudah memenuhi indikator lapisan pemahaman berdasarkan teori pirie-kieren. Hal ini sesuai pendapat Komariyah, Septi, Afifah, \& Resbiantoro (2018) bahwa mampu menerapkan konsep secara algoritma serta menyajikan dalam bentuk representasi yang benar.

Pada tahap kelima yaitu lapisan ke-5/Formalising, subjek penelitian sudah mampu membentuk dan menemukan konsep sendiri yang digunakan untuk menyelesaikan TLP2G. Konsep-konsep baru tersebut diperoleh subjek penelitian dengan mengumpulkan informasi pada soal, mengingat kembali konsep-konsep terdahulu yang tersimpan pada memory pekerjanya, mengaitkan konsep terdahulu dengan konsep yang baru saja dipelajari terkait konsep grup, dan menggabungkan konsep-konsep tersebut menjadi satu kesatuan yang menghasilkan konsep baru. Konsep baru inilah yang digunakan subjek penelitian untuk membuktikan grup pada TLP2G.

Pada tahap keenam yaitu lapisan ke-6/Organising, subjek penelitian sudah mampu mengorganisasi konsep yang ditemukannya sendiri yang digunakan untuk menyelesaikan TLP2G. Konsep-konsep baru tersebut memiliki pola atau struktur yang mampu dibentuk sendiri oleh subjek penelitian. Pengorganisasian konsep secara terstruktur dan sistematis pada ranah kognitifnya, memudahkan subjek penelitian menyelesaikan soal pada TLP2G.

Pada tahap ketujuh yaitu lapisan ke-7/structuring, subjek penelitian sudah mampu juga mengaitkan rumus-rumus yang sudah dikumpulkan, untuk ditarik ataupun membentuk rumus baru yang digunakan untuk membuktikan TLP2G. Rumus-rumus yang terbentuk dari pemikiran subjek penelitian sesuai digunakan untuk menyelesaikan TLP2G di dasarkan juga pada argumen logis dari subjek penelitian. Hal ini sesuai dengan penelitian Aisah (2017) yang menyatakan bahwa siswa yang memiliki kemampuan maematika tinggi dalam menyelesaikan soal logaritma dapat mencapai kedelapan lapisan pemahaman. 


\section{Simpulan}

Lapisan pemahaman mahasiswa calon guru matematika dengan tipe middle ability dalam menyelesaikan soal TLP2G, yaitu lapisan primitive knowing, image making, image having, property noticing, formalizing, observing, dan structuring. Subjek dalam penelitian ini sudah memenuhi indikator lapisan pemahaman pada level ke-7, dalam hal ini subjek sudah mampu memiliki pengetahuan dasar dalam menyelesaikan soal, membuat gambaran dari pengetahuan dasar tersebut, memiliki gambaran dari pengetahuan tersebut, memperhatikan sifat-sifat dari gambaran tersebut lalu memformalkan pengetahuan tersebut, subjek mampu melakukan pengamatan dari penyelesaian soal tersebut mulai dari penstrukturan dari pengetahuan tersebut, dan subjek sudah mampu menciptakan suatu pemahaman sendiri. Namun pada level ke-8 yaitu inventising, subjek penelitian masih belum mencapai tahapan tersebut karena subjek penelitian belum mampu membuat dan menyimpulkan persoalan yang baru saja diselesaikan untuk membentuk konsep baru atau mengorganisaikan semua pengetahuan dan pengalaman dari penyelesaian TLP2G. Untuk penelitian selanjutnya, peneliti menyarankan agar tidak hanya ditinjau dari aspek kemampuan matematika saja, tetapi pada aspek lain yang mempengaruhi pemahaman mahasiswa terhadap materi yang dipelajari.

\section{Daftar Rujukan}

Aisah, S. (2017). Profil Lapisan Pemahaman Dan Folding Back Siswa SMA Dalam Menyelesaikan Soal Logaritma Ditinjau Dari Kemampuan Matematika. UIN Sunan Ampel.

David E. Meel, "Models and Theories of Mathematical Understanding: Comparing Pirie and Kieren's Model of The Growth of Mathematical Understanding and APOS Theory", CBMS Issue in Mathematical Education, 12, (2003), 133.

Devi Rovina. 2014. "Kreativitas Siswa SMP dalam Memecahkan Masalah Luas Bangun Datar Sisi Lurus Ditinjau dari Kemampuan Matematika".

Jung, Inchul. 2002. Doctoral Dissertation: "Student Representation and Understanding of Geometric Transformations with Technology Experience". Georgia: The University of Georgia.

Kelli M. Slaten. 2010. "Effective Folding Back via Student Research of The History of Mathematics", Proceedings of The 13th Annual Conference on Research in Undergraduate Mathematics Education

Komariyah, S., Septi, D., Afifah, N., \& Resbiantoro, G. (2018). Analisis pemahaman konsep dalam memecahkan masalah matematika ditinjau dari minat belajar siswa. SOSIOHUMANIORA: Jurnal Ilmiah Ilmu Sosial dan Humaniora, 4(1), 1-8. https://doi.org/dx.doi.org/10.30738/sosio.v4i1.1477.

Kusaeri, "Acuan E Teknik Penilaian Proses \& Hasil Belajar dalam Kurikulum 2013" (Yogyakarta: ArRuzz Media, 2014). 
Luvia F. P \& Janet. 2016. “Identifikasi Kemampuan Matematika Siswa dalam Memecahkan Masalah Aljabar di Kelas VIII Berdasarkan Taksonomi SOLO", diakses dari http//jurnalmahasiswa.unesa.ac.id.

Martin, LaCorix, and Fownes. 2005. "Folding Back and The Growth of Mathematical Understanding in Workplace Training", Mathematics Education Research Journal, 1: 1,

Milda Retna, Lailatul Mubarokah, dan Suhartatik. 2013. "Proses Berpikir Siswa Dalam Menyelesaikan Soal Cerita Ditinjau Berdasarkan Kemampuan Matematika", Jurnal pendidikan Matematika STKIP PGRI Sidoarjo, 1: 2

Pirie, S., $\quad$ T. $\quad$ E. $\quad$ Kieren. 1994. "Beyond Metaphor:Formalisingin

Mathematical Understanding within Constructivist Environments". For the Learning of Mathematics. Vol. 14 No. 1, 39-43.

Purwanto, Ngalim. 2007. Psikologi Pendidikan Remaja. Bandung: Rosdakarya

Sagala, Viktor. 2016. “Profil Lapisan Pemahaman konsep turunan fungsi dan bentuk folding back mahasiswa calon guru berkemampuan tinggi berdasarkan Gender". MATHEdunesa Jurnal Ilmiah Pendidikan Matematika. Vol. 4 No. 1, 42-47.

Sugiyono. 2012. Memahami Penelitian Kualitatif. Bandung: C.V. Alfabeta.

Susiswo. 2014. "Folding Back Mahasiswa dalam Menyelesaikan Masalah Limit Berdasarkan Pengetahuan Konseptual dan Pengetahuan Prosedural", Prosiding Seminar Nasional TEQIP (Teachers Quality Improvement Program) Universitas Negeri Malang,(Desember, 2014)

Tim Penyusun Kamus Pusat Bahasa, “Kamus Besar Bahasa Indonesia” (Jakarta: Balai Pustaka, 2002)

Utami, I. W., A. H. Rosyidi. 2016. "Profil Lapisan Pemahaman Property Notiching siswa Pada Materi Logaritma ditinjau dari Perbedaan Gender". MATHEdunesa-Jurnal Ilmiah Pendidikan Matematika. Vol. 1 No. 5, 22-24. 
Novita Eka Muliawati 